\title{
INTEGRATED ANALYSIS OF MAGNETIC AND GEOLOGICAL DATA IN THE STUDY OF A SEISMOGENIC ZONE IN CENTRAL BRAZIL
}

\author{
Almo, P.M11., Curto Ma, J.B¹., Peixoto, E.I.N1․ Instituto de Geociências - Universidade de Brasília \\ Copyright 2021, SBGf - Sociedade Brasileira de Geofísica. \\ This paper was prepared for presentation during the $17^{\text {th }}$ International Congress of the Brazilian Geophysical Society held in Rio de Janeiro, Brazil, $16-19$ August 2021. \\ Contents of this paper were reviewed by the Technical Committee of the $17^{\text {th }}$ International Congress of the Brazilian Geophysical Society and do not necessarily represent any position of \\ the SBGf, its officers or members. Electronic reproduction or storage of any part of this paper for commercial purposes without the written consent of the Brazilian Geophysical Society is
} prohibited.

The Transbrasiliano Lineament (TBL) is a major structural feature of the South American platform. Formed at the end of the Brasiliano tectonic event, in the Neoproterozoic, this large structural zone hosted many tectonic reactivations in the region between the states of Goiás (GO) and Mato Grosso (MT), Brazil, where the Araguaia River reveals the main direction of the TBL (NE-SW). In the city of Araguaiana (MT), between 1996 and 1998, occurred approximately 416 earthquakes, and in 2017 a seismic event of magnitude $3.4 \mathrm{mR}$ was registered. The study area includes three tectonic domains and geological units from the Parana Basin, Paraguay Belt, Arenopolis Magmatic Arc, Goias Alkaline Province (GAP) and the Cenozoic alluvial coverage. The geological and tectonic complexity of the area shows the importance of studying its evolution and recent dynamics. Therefore, the objective of this study was the analysis of magnetic features nearby the city of Araguaiana, at different depths, and classify them according to the main structural directions and their relationship with the tectonic compartments. We used the Oasis Montaj (Geosoft) and ArcGIS (Esri) software to process the data. The following geophysical projects were made available free of charge by the Brazilian Geological Survey (CPRM), the Brazilian National Nuclear Energy Commission (CNEN) and the Secretary of Industry and Commerce of the State of Goias/Brazilian Ministry of Mines and Energy (SIEG/MME): Ipora, Barreiro and Arco Magmático of Arenopolis-Juscelândia Sequence. The analysis scale was 1:25,000. The first step of the methodology was based on the delimitation of magnetic domains related to intensity, texture differences and magnetic relief of the total gradient amplitude product. Five classes were defined and related to the geological units. Finally, we extracted magnetic lineaments from the Tilt derivative at 4 depth intervals, estimated by the Euler Deconvolution. The results show an inverse correlation between the magnetic depth and the number of lineaments over the Euler solutions. The lineaments of all depth levels has an overall mean of $\mathrm{N} 48^{\circ} \mathrm{W}$ (strike), indicating a preferred NE-SW direction. (1) The shallower level $(0-500 \mathrm{~m})$ showed more precise directions in the midwestern part of the area, which outcrops the Araguaia formation and the GAP. (2) At the 500-1000m level, the western solutions are relate to the rocks of the Paraná Basin, Paraguay Belt and Cenozoic coverage. (3) At $1000-2000 \mathrm{~m}$, western lineaments still remained and at (4) $2000-4000 \mathrm{~m}$, solutions to the southwest prevailed, related to the rocks of the Parana basin. The NE trend at all depths was important to characterize the region as an TBL-controlled zone. The magnetic domains showed the difference between provinces as well as the preferred direction. These results lead us to point the TBL as an important control in the deposition of the sediments in the study area through different reactivation events in the Phanerozoic, and maybe is still controlling the neotectonics processes and current surface dynamics in this region. 